puts it admirably: "The planning of the river's future is entrusted to the T.V.A. The planning of the valley's future must be the democratic labour of many agencies and individuals and final success is as much a matter of general initiative as of general consent. The T.V.A. has no power or desire to impose from above a comprehensive plan for the social and economic life of the Valley."

\section{INSULATION OF HEATING SYSTEMS}

A. C. PALLOT gave a Cantor Lecture to the A Royal Society of Arts on "Thermal Insulation at Medium Temperature" on November 23; the lecture, which included many topics of current interest, has now been published ${ }^{1}$.

In a bulletin on heat insulation issued by the Ministry of Fuel and Power, it was pointed out that "In the national drive for fuel economy there is probably no single factor, which is common to all industries using heat in its many diverse applications and can produce a greater saving in fuel, than efficient insulation. The reduction of heat loss by insulation is a practical means of achieving a substantial economy in fuel by using materials which are available and can generally be easily and quickly applied without interruption to operation or to process routine"2. Comparative neglect of insulation is apparent in many industrial, commercial, and domestic buildings. In some industrial premises taken over by the Government, all the calorifiers, pipes and connexions were devoid of lagging, long lengths of main steam piping were exposed to the weather and were completely bare, and the entire condensate was allowed to run to waste.

The temperature range $100-400^{\circ} \mathrm{F}$. covers all normal heating, ventilation and hot-water supply systems, as well as many industrial steam installations, accounting for the use of 60 million tons of fuel yearly - a quarter of the total output of Great Britain. Even a small fractional saving of fuel by the use of insulation would mean a substantial economy in national resources. Many quantitative data given in the lecture show that a highly polished metal surface is quite a good insulator. A given thickness of insulation is more effective on a large pipe than on a small one. 'Insulation' with unsuitable materials may actually increase the heat loss from small-diameter pipes. The first layer of insulation is more effective than subsequent layers in spite of the fact that a greater volume of insulating material is needed for each successive concentric ring. Insulating materials in common use vary from crumpled aluminium foil, reducing radiation losses, to asbestos, magnesia, glass silk and slag wool, reducing losses by conduction. Even aluminium paint will save about half the normal radiation losses. Under ordinary conditions the domestic 25-gallon cylinder loses heat by radiation equivalent to about $5 \mathrm{lb}$. of fuel a day. Insulation of such a cylinder in constant use would save about half a ton of fuel per annum.

The physical factors affecting heat losses are simple compared with those involved in calculating the economic thickness of insulation. A calculation made of the thickness of a given insulator needed to save a definite percentage of the bare surface loss shows that the thickness diminishes as the temperature increases. This is contrary to ordinary practice, but the 10 per cent of heat still lost through the insulation increases rapidly with the working temperature and a thinner layer of insulation will allow this to pass. A calculation of the most economical thickness of insulation will have to take account of the annual cost of the heat produced and the interest and depreciation charges on the proposed insulation. Both internal and external temperatures will vary throughout the day as well as throughout the year. The cost of the heat lost will depend upon both the cost of fuel and upon boiler efficiency. Hours of operation per annum must be considered, for the loss of heat is continuous while the boiler is in use, but some plants work throughout the year whereas others work seasonally or intermittently. Among these factors the thermal conductivity is the simplest occurring in the calculations, examples of which are given. Special attention is given also to the use of emergency materials as substitutes for orthodox insulator which may be unobtainable in war-time.

In the second part of the lecture, dealing with the insulation of structures, it is pointed out that the modern tendency to build light structures may considerably increase the amount of fuel needed to keep their interiors at a comfortable temperature. Not only will thin walls and roofs allow easy transmission of heat but also, if the walls are at a lower surface temperature, a higher air temperature must be maintained inside. In a well-planned building the initial cost of insulation may be more than offset by the reduction in initial cost of a central heating system as well as by the subsequent reduced consumption of fuel. In addition to its thermal results, the insulation of buildings minimizes condensation, because of the higher surface temperatures. 'Pattern staining', due to the transfer of dust from the warmer to the colder areas of plaster, is reduced, and most thermal insulators are effective in absorbing sound. Further.' more, insulation of concrete roofs reduces expansion, which sometimes causes structural damage.

${ }^{1}$ J. Roy. Soc. Arts, 91, 122 (1943).

${ }^{2}$ Mines Dept. Fuel Efficiency Bulletin, No. 2 (1942).

\section{PREPARATION OF TEACHERS IN HEALTH EDUCATION}

$I^{\mathrm{T}}$

will be a happy day when we have in Great Britain a booklet corresponding to "Opportunities for the Preparation of Teachers in Health Education", issued by the U.S. Office of Education (Bulletin 1942 , No. 1). Written in the form of a survey of twenty Teachers Colleges, ranging from Massachusetts to California, this work presents a bird's-eye view of the training of U.S. teachers in this vital subject. It is clear that "health education" is conceived by the U.S. Office of Education as something very different from the traditional 'hygiene', and it is to be hoped that as a result of the deliberations of the Board of Education's McNair Committee on the Training of Teachers, a similar breadth of vision will permeate the training colleges of Great Britain.

Among the obstacles to the achievement of adequate health education courses in the United States are listed the slowness of administrators to recognize the need.for them and the lack of well-prepared health instructors -two causes potent also on this side of the Atlantic. Every training college lecturer and administrator in. Great Britain should study carefully these detailed. 
descriptions of twenty courses, and none can fail to reap some benefit from their reading.

A fairly typical programme is that of the San Diego State College in California, which offers courses (some "Required", some "Elective") in the science of life, health and social adjustments, human physiology, physiology of exercise, safety education, general bacteriology, embryology, genetics, mental hygiene, physiology of reproduction, physiology of infancy and childhood, and man and his biological world. No doubt at San Diego as elsewhere, achievement falls short of ideal, but at least the ideal is a high one.

An appendix gives details of colleges and universities in the United States offering courses in health education during the summer session of 1941 . No fewer than forty-six are listed-whereas in Great Britain educationists wishing to equip themselves in this field during the summer vacation will be very largely dependent upon courses arranged by bodies such as the Central Council for Health Education.

The U.S. Office of Education is by no means satisfied with the state of affairs shown by this investigation. "Far too many pseudo-health educators and semicultists hold positions of responsibility in the public schools to-day simply because school administrators have either been unwilling or unable to lend themselves to this problem of teacher preparation in health education"; and it is equally true in Great Britain that this "should be sufficient reason why in these stirring times every effort should be put forth to improve on the present situation".

\section{FORTHCOMING EVENTS}

\section{Saturday, May 22}

Nutrition SocikTY (at London School of Hygiene and Tropical Medicine, Keppel Street, London, W.C.1), at 10.30 a.m. - Conference on Nutrition in Infancy.

BRITISH INSTITUTE OF RADIOLOGY (at 32 Welbeck Street, London, W.1), at 2.15 p.m.-Annual General Meeting.

Free German Institute of Science and Learning (at 16 Buckland Crescent, London, N.W.3), at 5 p.m.-Dr. G. Coumoulos: "The Greek Scientists-Traditions and Ties".

\section{Monday, May 24}

Royal Society of ARts (at John Adam Street, Adelphi, London, W.C.2), at 1.45 p.m.- Prof. H. V. A. Briscoe: "Some New Properties of Inorganic Dusts", (Cantor Lectures, II).

Copernicüs QUATERCenteinary Chlebration Committee (at the Royal Institution, 21 Albemarle Street, London, w.1), at 3.30 p.m.weeting in honour of Nicolaus Copernicus. (Sir Henry Dale, P.R.S., Jones, F.R.S., will deliver addresses).

\section{Tuesday, May 25}

Royal College of Physiclans (at Pall Mall East, London, S.W.1), at 2.45 p.m.-Air Commodore C. P. Symonds: "Flying, Stress" (Croonian Lectures, 1).

\section{Wednesday, May 26}

ROYal SocIE'y of ARTs (at John Adam Street, Adelphi, London, W.C.2), at 1.45 p.m.-Mr. John Gloag: "The Influence of Plastics on Design".

INSTITUTK OF WELDING (at the Institution of Civil Engineers, Great George Street, London, S.W.1), at 6 p.m.-Mr. H. W. G. Hignett: "Welding Research and Development in the United States of America".

\section{Thursday, May 27}

ELECTRICAI A SSOCLATION FOR WOMEN (at the Institution of Electrical Engineers, Savoy Place, Victoria Embankment, London, W.C.2), at 2 p.m.-Annual General Meeting ; at 3.30 p.m.-The Rt. Hon. Viscount Samuel: "An Electrified Future" ROYAL College of PHYsicians (at Pall Mall East, London, S.W1.),
at 2.45 p.m.-Air Commodore C. P. Symonds: "Flying Stress" (Croonian Lectures, 2).

\section{Friday, May 28}

ROYAL INSTITUTION (at 21 Albemarle Street, London, W.1), at 5 p.m. Miss L. Evelyn Cheesman : "The Island of New Guinea".

Saturday, May 29

Free German Institute OF Science $\triangle$ ND Learnisg (at 16 Buckland Crescent, London, N.W.3), at 5 p.m.-Capt. Helmer Dahl:

\section{APPOINTMENTS VACANT}

Applications are invited for the following appointments on or before the dates mentioned:

OCCUPATIONAL THERAPIST TO TAKE CHARgE OF THE SCHOOL OF OcCUPATIONAL TherapY - The Medical Superintendent, St. Andrew's Hospital, Northampton (May 28).

ASSISTANT LECTURER IN CHEMISTRY-The Bursar and Acting Registrar, University College of North Wales, Bangor (May 29).

LECTURER IN CHARGE OF THE BIOLOGY DEPARTMENT-The Principal Technical College, Wigan (May

Technical College, Wigan (May 29).
DIETICIAN (NON-RESIDENT) TO ASSIST MEDICAL STAFF IN DIETARY DIETICIAN (NON-RESIDENT) TO ASSIST MEDICAL STAFF IN DIETARY
OF IN- AND ODT-PATIENTS at West Middlesex County HospitalMedical Superintendent 'R.2', West Middlesex County Hospital, Isleworth (May 29).

LECTURER IN MATHEMATICS-The Secretary, Woolwich Polytechnic, Woolwich, London, S.E.18 (May 31).

TWO TEACHERS TO TAKE EITHER (1) METALWORK OR (2) ScIENCE AND MATHEMATICS, in the Junior Technical and Day Continuation Technology and Arts, Fastlands, Rugby (May 31) Technology and Arts, Eastlands, Rugby (May 31).

WOMAN GARDENER (non-resident) to prepare students for Horticulture as a subject of the Teachers' Certiflcate-The Principal, The Training College, Hereford (May 31).

CHAIR OF ELECTRIOAL ENGINEERING - The Secretary and Registrar, The University, Bristol (June 1).

LECTURER IN ENGINEERING DRAWING, including the teaching of Workshop Practice and/or General Engineering Subjects, in the Oxford Schools of Technology, Art and Commerce-The Chief Education Officer, City Education Office, 77 George Street, Oxford (June 2). TEACHER OF MATHEMATICS, and a TEACHER OF ENGINEERING DRAwING AND PRAcTICAL GEOMETRY-The Principal, Technical College, Church Street, Barnsley (June 5).

TEACHER FOR MATHEMATICS AND MECHANICS in the Technical School-The Director of Education, City Hall, Norwich (June 5).

ADVISORY OFFICER IN PLANT PATHOLOGY (PLANT HUSBANDRY)-
The Secretary, West of Scotland Agricultural College, 6 Blythswood The Secretary, West of Scot

DEMONSTRATOR, (MAN OR WOMAN) IN THE PHYSICS DEPaRTMRNT in London-The Warden and Secretary. London (Royal Free Hospital) School of Medicine for Women, Reed Hall, Streatham Drive, Exeter. (June 15).

Director of the Transvaal MUSeum, Pretoria-The Secretary, Office of the High Commissioner for the Union of South Africa, South Africa House, Trafalgar Square, London, W.C.2 (June 26).

LECTURER IN ANIMAL HUSBANDRY at the Imperial College of Tropical Agriculture in Trinidad-The Acting Secretary, Imperial College of Tropical Agriculture, Grand Buildings, Trafalgar Square, London, W.C.2 (June 30).

LECTURER IN GEOGRAPHY AND MATHEMatics-Tho Principal, The Training College, Norwich.

A SENIOR Post UNDER THE A ERONAUTiCaL INSPECTION Directorate (applicants should possess a degree in physics or recognized equivalent and have an extensive knowledge of non-metallic materials, with a specialized knowledge of the production of Paints and Allied Products ; Rubbers-Natural and Synthetic ; Aircraft Dopes ; Plastics, Glues, Cements ; or Aircraft Textiles)-Ministry of Labour and National Service (Ref. A.224), Alexandra House, Kingsway, London, W.C.2.

HORTICULTURAL INSTRUCTOR for Boys' Intermediate Approved School-The Headmaster, St. Joseph's School, Nantwich, Cheshire. GENERAL SECRETARY of the Institution of Production EngineersW.1.

Mechanical Superintendent for the Ceylon Government Irriga( Central (Technical and Scientific) Register (Ref. C.1662), Alexandra House, Kingsway, London, W.C.2

SENIOR ASSISTANT DRAINAGE AND IRRIGATION ENGINEER for the Government of Sierra Leone-Ministry of Labour and National Service, Central (Technical and Scientifle) Register (Ref. F.595), Alexandra Couse, Kingsway, London, W.C.2.

CHIEF INSTRUMRNT ENGINEER (Ref. C.1420) and an AssistanT INSTRUMENT ENGINEER (Ref. C.1663X) for work at Trinidad, British West Indies-Ministry of Labour and National Service, Central London, W.C.2

ROAD ENGINEer for the Government of Kenya Public Works Department $\rightarrow$ Ministry of Labour and National Service, Central (Technical and Scientiflc) Register (Ref. E.656), Alexandra House, Kingsway, London, W.C.2.

DEMONSTRATOR -(MALE) IN THE DePartMent of BIOLOGY-The Secretary, St. Mary's Hospital Medical School, Paddington, London, W.C.2.

Thacher of Mathematics, Mechanios and Elementary Scienoe, a TEACHER OF ENGINEERING (Mechanical) SUBJECTS qualifled to take Workshop Practice, and a TEAcher of BUILDING SUBJECTS-The Principal, Erith Technical College, Belvedere, Kent.

assistant Master for Mathematics and ScIence, with Physical TRAINING AND GAMES, at the Atkinson Road Junior Technical School, Newcastle-upon-Tyne-The Director of Education, City Education Office, Northumberland Road, Newcastle-upon-Tyne 2.

LEcTURER IN ScIENcE-The Principal, Hockerill College, Bishop's Stortford.

IAABORATORY ASSISTANT FOR WORK IN BIOCHEMISTRY DEPARTMENT -The Secretary, London Hospital Medical College, Turner Street, London, E.1.

Assistant Cultrvation OfFicers-The Executive Officer, Cumberland War Agricultural Executive Committee, 6 Brunswick Street, Carlisle.

Chimf Industriat Planning Opficer under the Government of INDIA FOR SURGICAL INSTRUMENT PRODUCTION-The Ministry of Labour and National Service, Central (Technical and Scientific) 